Jasmina P. Đorđević ${ }^{1}$

Faculty of Philosophy

University of Niš

Savka N. Blagojević ${ }^{2}$

Faculty of Philosophy

University of Niš

\title{
PROJECT-BASED LEARNING IN COMPUTER-ASSISTED LANGUAGE LEARNING: AN EXAMPLE FROM LEGAL ENGLISH ${ }^{3}$
}

The research presented in this paper aims at exploring the effectiveness of Project-Based Learning (PBL) when applied in a specifically designed Computer-Assisted Language Learning (CALL) setting in the context of practising writing skills. The initial hypothesis of this research was that PBL in a CALL setting within a Legal English (LE) as an English for Specific Purposes (ESP) course may improve students' writing skills. For that purpose, a two-week project was carried out with 20 third-year English language students who were presented a specific issue from LE, unfair dismissal in Employment Law, by means of a webquest as an online inquiry-oriented activity. The specific objective was to explore whether the students were able to draft a written claim based on digital resources provided to them through the webquest. Based on rubrics, the assessment of the final written products submitted by the students revealed that PBL did contribute to the practice of students' writing skills in an ESP course based on CALL, but only to a certain extent. The assessment scores analysed in the experiment reflected an overall improvement of student performance in comparison to their usual performance. However, the assumption that PBL in a CALL setting enables students to make adequate choices regarding the selection and use of proper resources provided to them could not be fully confirmed, thus leaving an open door to subsequent research to explore the issue under consideration.

Keywords: Project-based learning, CALL, Legal English, writing skills

\section{Introduction}

Since the research presented in this paper is intended as a contribution to numerous investigations within Computer-Assisted Language Learning (CALL), it should be noted that, regardless of many proven advantages, this

1 jasmina.djordjevic@filfak.ni.ac.rs

2 savka.blagojevic@filfak.ni.ac.rs

3 This paper is a part of the National Project No. 17814, sponsored by the Ministry of Science and Education of the Republic of Serbia. 
young branch of applied linguistics is still establishing its directions (Beatty 2013). In addition, more elaborate theoretical explorations are needed for a firmly grounded framework of CALL with clearly outlined pedagogical implications (cf. Hall et al. 2011; Levy and Stockwell 2013). Thus, a general recommendation regarding CALL is that research agendas in this area should be based on applied linguistics, language pedagogy and language learning (Reeder et al. 2013) focusing both on the pedagogical implications of CALL (Colpaert 2006) and on the possibility of providing theoretical innovation within CALL (Cerezo 2015).

The changes occurring in language learning methodology provoked a shift of focus in CALL as well. For example, Chapelle (1997) suggested focusing research on methods complementing the understanding of the language experience learners have in a CALL setting while Colpaert (2006) argued for a need of a pedagogy based on the advantages and the innovative features of CALL as a new medium. Another study (Herring et al. 2014) urged that CALL, just as any other teaching approach, must rely on content, pedagogy and technology. In support of the new directions within CALL, the Executive Committee of the European Association for Computer Assisted Language Learning (EUROCALL) decided in 2010 that the Research Policy Statement formulated in 1999 had to be revised to account for the obvious changes in CALL (EUROCALL Research Policy Statement 2010). Thus, the research focus shifted from exploring the availability of new technologies and functionalities in CALL to developing language pedagogies, i.e. techniques and procedures of teaching by using them (Fotos and Browne 2013; Nim Park and Son 2009).

Following the outlined recommendations, the research presented here is aimed at examining the learning results of an established teaching method when applied in a CALL setting. Precisely, we examine the possibility of improving students' writing skills in Legal English when Project-based learning (PBL) is used within CALL, as well as to what extent the application of this method may help students to draft a written legal claim based on exploring, selecting and using digital resources provided to them in a CALL environment.

Before answering these questions, two crucial concepts underlying our research - Project-Based Learning and webquests - will be explained briefly.

\subsection{Project-Based Learning (PBL) in the language classroom}

Referred to as a teaching model that organizes language learning around projects (Barrett et al. 2013; Thomas et al. 1999), PBL is a set of complex tasks involving students in investigative activities. Students are expected to solve problems, make decisions and produce products which reflect their actual use of language. That is why PBL is deemed to function "as a bridge between using English in class and using English in real life situations outside of class" (Fried-Booth 2002: 5).

However, PBL is considered problematic due to the fact that the variety of practices under its banner makes it difficult to determine what a real project is (Tretten and Zachariou 1997). Moreover, the label of the teaching model 
itself is disputed as PBL is also referred to as intentional learning (Scardamalia and Bereiter 1991), design experiment (Brown, 2001) and quite often as problem-based learning (Gallagher et al. 1992). Nevertheless, an obvious benefit of PBL is its effectiveness as teachers may use authentic content, define explicit educational goals, facilitate the teaching process without directing it, enhance cooperative learning and reflection among students as well as assess language use in more or less simulated real-life situations (Diehl et al. 1999).

\subsection{PBL and writing skills in Legal English}

When referring to the skill of writing at university level, students' written products are expected to derive "from research practice: the routines, habits, and values which motivate scholars to do the work they do" (Giltrow et al. 2009: 10). Accordingly, the skill of writing in a Legal English course should meet the objectives of the ESP course, i.e. students are expected to write about problems from the context of law (e.g. court procedures, administrative processes, etc.) by relying on the terminology, register, style and forms of written text used in that context (e.g. affidavits, briefs, contracts, writs, etc.).

Therefore, PBL seems to be quite appropriate in the context of practising writing skills as it engages students in constructive investigation (Bereiter and Scardamalia 1999; Fried-Booth 2002), implements experiential learning (Eyring 2001; Kohonen et al. 2014), enhances learner autonomy (Benson 2013), fosters cooperative learning (Trentin 2009) and provides a solid basis for critical thinking and independent expression of thoughts in writing (Adams and Hamm 1996).

\subsection{Application of PBL in a CALL setting}

The idea to apply PBL in a CALL setting derived from previous research which proved that CALL allows for the implementation of a variety of authentic online material (Authors of this article 2016; Vanderplank 2010) and it fosters individual and autonomous learning (Murphy 2008). In addition, by furthering self-correction and error management skills, CALL may contribute to a rise in self-confidence (Hyland 2000) and by implementing challenging content, it motivates students to work harder (Cheng and Dörnyei 2007).

By combining CALL and PBL, additional benefits may be expected, such as a structured and well-organized, yet authentic context for collaboration and social interaction in which learners construct the knowledge of the target language on their own while engaged in meaningful activities (Simina and Hamel 2005). At the same time, the use of online tools (e.g. blogs, wikis, workspaces, etc.) contributes to creating a community of inquiry driven by sharing knowledge and exchange of ideas (Krajcik et al. 1994). 


\subsection{Webquests in $P B L$}

Webquests are inquiry-oriented activities in which some or all the information that learners interact with comes from the Internet (Felix 2002). Learners are provided with an original scenario and background information to help them accomplish a certain task. In addition, webquests contain links that point to websites where students will find extra information so that they spend less time looking for it. The students are encouraged to engage in social interaction by collaborating in an authentic language context, which they can perform via the computer at a pace and in a setting they themselves can control and manage (Dodge 1995).

Based on the conclusions outlined in the theoretical framework, a smallscale empirical research was conducted to test the effectiveness of PBL in CALL for the purpose of practising writing skills. The details are presented in the next section.

\section{The research}

\subsection{Hypothesis and aims}

The research presented here was based on the assumption that PBL as a standard teaching method when employed in a CALL setting may contribute to students' writing skills. For this purpose, PBL was tested by means of a specially designed webquest in an advanced Legal English (LE) course. The students were expected to rely on guided instruction presented to them in a webquest, use provided digital resources and draft a written claim based on them. The objective was to confirm two research questions proposed at the beginning of the experiment: (1) Does PBL based on a CALL setting contribute to student writing skills? and (2) To what extent will PBL facilitate students' abilities to draft a written legal claim based on exploring, selecting and using digital resources provided to them in a CALL environment?

\subsection{Sample and setting}

The PBL teaching method was tested during one semester within a LE course ${ }^{4}$ with 20 third-year students ( 8 male and 12 female students) at average 21 years old. Their faculty curriculum comprises courses focused on theoretical and practical aspects of the English language as well as two obligatory three-semester ESP courses (Business English and Legal English). Through the LE course, the students are expected to understand the structure and system of law in an international context as well as to identify and work with specific legal issues (e.g. criminal procedures, contractual relationships, property issues, etc.).

4 The experiment took place at the Department of English language at the Faculty of Law and Business Studies in Novi Sad in the academic year 2014/2015. 
In this research, PBL was based on a webquest prepared for the students prior to the research. ${ }^{5}$ The students were expected to follow the detailed instructions, explore the links to online resources, select information from them and write a Claim for Unfair Dismissal to the Employment Tribunal. The instruction model followed the conventional Presentation-Practice-Production (PPP), i.e. a traditional activity sequencing pattern used in language teaching (cf. Carless 2009; Cook 2013; Swan 2005) because it suited the gradual guided instruction prepared for this experiment.

The presentation step was conducted in class based on the webquest, where the students learned about claims in general and the purpose of writing claims was illustrated to them in reference to an employment issue a person named Tom was having (see Figure 1).

\section{Let's get Tom's job back!}

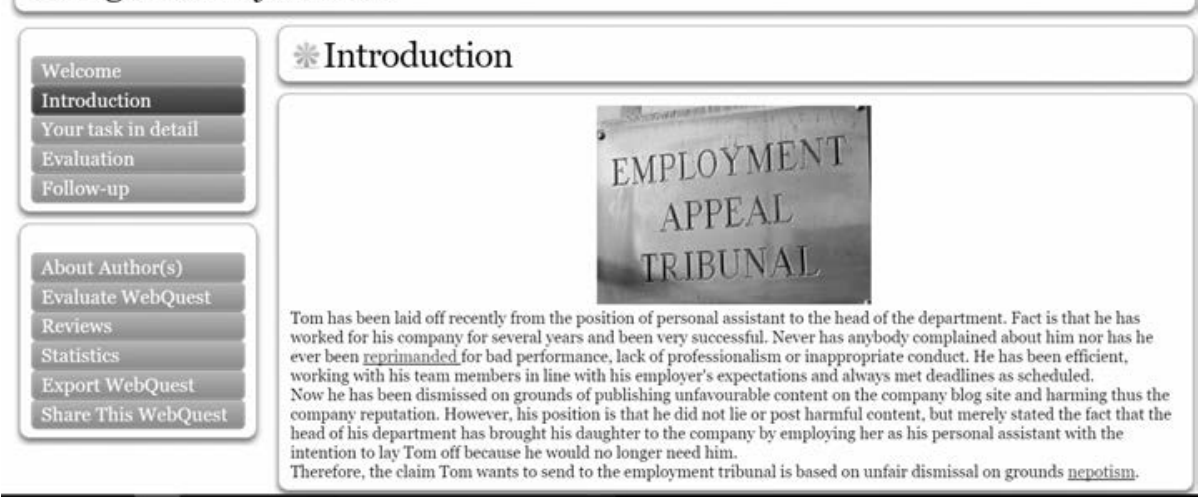

Figure 1. Illustration of the Presentation step

During the second practice step, the students worked at home, guided by the instruction provided in the webquest in the section "Your task in detail" (see Figure 2).

5 Available at http://zunal.com/webquest.php?w=170859. 


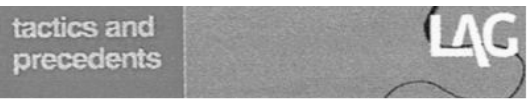

1. Go to Unfair dismissal and read about unfair dismissal, the types, the reasons and the explanations related to each

2. Make a list of possible facts, phrases, words you could use for Tom's case.

3. Download the file called "Your claim" from the panel below and complete it for Tom.

4. Go to the page "Evaluation" (the link is in the sidebar to the left) and make sure you refer to the guidelines set out for you to help you submit a well-drafted claim.

5. Send "Your claim" to djordjevic.jasmina@gmail.com

6. Go to Take your employer to the tribunal and take a look at the procedure referring to the steps to take after unfair dismissal has been established.

7. Make a list of supporting evidence, documents and other relevant supporting arguments your boss will take to the hearing.

8. Send the list to djordjevic.jasmina@gmail.com

\section{Unfair dismissal}

\section{Take your employer to the tribunal}

\section{Your Claim document}

Figure 2. Illustration of the Practice Step

After that, the students were expected to read the additional material (see Figure 3 and Figure 4), compile basic information and make their own choices with respect to the amount of information they would actually use and incorporate in their claims. Finally, the students were asked to complete the production step by drafting their claims based on the template provided in the instructions and submit their writing per email to their teacher.

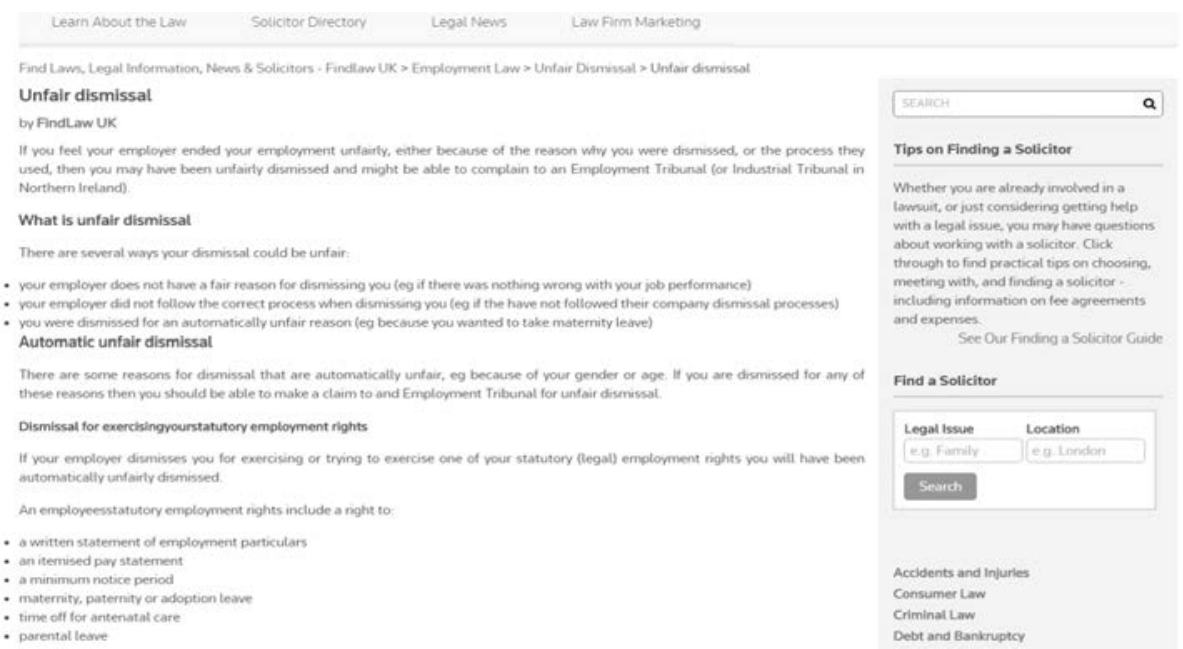

Figure 3. Illustration of additional material related to unfair dismissals 


\section{GOV.UK}

Search

\section{Make a claim to an employment tribunal}

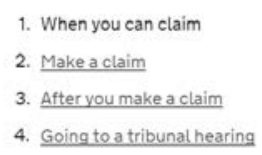

5. If you win your case

6. If you lose your case

7. Legislation
Courts, sentencing and tribunals

Being taken to an employment tribunal More

Elsewhere on GOV.UK

Dismissal:your rights

Redundancy: your rights

Solve a workplace dispute

\section{When you can claim}

You can make a claim to an employment tribunal if you think someone has

Figure 4. Illustration of additional material related to making claims

\section{Discussion and results}

Despite the obvious limitations of the experiment (restriction in time, space and the number of participants, the lack of a control group, the students' external motivation to perform better so as to pass the final, the limited objective of the tasks focusing only on writing skills, etc.), the results obtained from the experiment are relevant and worth discussing. Prior to presenting them, a brief explanation of the assessment procedure applied in the experiment should be provided.

\subsection{Assessment procedure}

The evaluation criteria for the individual writing assignments in the experiment were based on rubrics, an assessment tool usually applied for the evaluation and assessment of students' written language production. Rubrics are based on a predefined set of clearly and precisely articulated expectations by listing criteria and describing levels of quality (Stephens and Randall 2011). The evaluation criteria defined for this research were the same as the ones usually defined for the essays students wrote for their LE exam, i.e. two criteria were defined: ideas/research questions defined $(\mathrm{Cl})$ and - the quality of the sources used (C2). With respect to the levels of quality, all essays were rated on a scale of 1 to 4 (below standard, approaching standards, meets standards and above standards) (see Table 1). 


\begin{tabular}{|c|c|c|c|c|c|}
\hline $\begin{array}{c}\text { Score } \\
\text { Category }\end{array}$ & 4 & 3 & 2 & 1 & Total \\
\hline $\begin{array}{c}\text { Ideas/ } \\
\text { Research } \\
\text { Questions } \\
\text { (C1) }\end{array}$ & $\begin{array}{l}\text { Students } \\
\text { identify at least } \\
4 \text { reasonable, } \\
\text { creative ideas/ } \\
\text { questions, } \\
\text { closely related } \\
\text { to the case and } \\
\text { pursue them } \\
\text { when doing } \\
\text { the research. }\end{array}$ & $\begin{array}{l}\text { Students } \\
\text { identify at least } \\
2 \text { reasonable } \\
\text { ideas/ } \\
\text { questions, } \\
\text { closely related } \\
\text { to the case and } \\
\text { pursue them } \\
\text { when doing } \\
\text { the research. }\end{array}$ & $\begin{array}{l}\text { Students } \\
\text { identify ideas/ } \\
\text { questions } \\
\text { only remotely } \\
\text { related to } \\
\text { the case and } \\
\text { pursue them } \\
\text { when doing } \\
\text { the research. }\end{array}$ & $\begin{array}{l}\text { Students } \\
\text { identify only } \\
\text { general ideas/ } \\
\text { questions and } \\
\text { pursue when } \\
\text { doing the } \\
\text { research. }\end{array}$ & \\
\hline $\begin{array}{l}\text { Quality of } \\
\text { Sources } \\
\text { (C2) }\end{array}$ & $\begin{array}{l}\text { Students locate } \\
\text { and use at } \\
\text { least } 2 \text { pieces } \\
\text { of reliable, } \\
\text { supporting } \\
\text { information } \\
\text { sources for } \\
\text { EACH of } \\
\text { their ideas or } \\
\text { questions. }\end{array}$ & $\begin{array}{l}\text { Students } \\
\text { locate and use } \\
\text { information } \\
\text { sources only } \\
\text { related to } \\
\text { their ideas or } \\
\text { questions but } \\
\text { not supporting } \\
\text { them. }\end{array}$ & $\begin{array}{l}\text { Students, } \\
\text { locate and use } \\
\text { only general } \\
\text { information } \\
\text { sources } \\
\text { remotely } \\
\text { related to } \\
\text { their ideas or } \\
\text { questions. }\end{array}$ & $\begin{array}{l}\text { Students, } \\
\text { locate and } \\
\text { use general } \\
\text { information } \\
\text { sources not } \\
\text { related to } \\
\text { their ideas or } \\
\text { questions. }\end{array}$ & \\
\hline
\end{tabular}

Table 1 . The scores and quality descriptors for the two assessment criteria

\subsection{Results}

In order to gain insight into the students' progress regarding their writing skills, a set of analyses was directed at comparing the scores the students achieved for their essays as part of their final exams in Legal English 2 (LE2) prior to the implementation of PBL and the essays they wrote as part of the experiment during Legal English 3 (LE3). The analyses yielded various results two of which seem most relevant for the research presented here.

The first result is related to the progress of the students regarding their writing skills. A comparison between the final scores the students achieved for their essays in both LE2 and LE3 was performed (see Table 2).

\begin{tabular}{|l|r|r|r|r|}
\cline { 2 - 5 } \multicolumn{1}{c|}{} & Mean & Std. Deviation & \multicolumn{1}{c|}{$\begin{array}{c}\text { Std. Error } \\
\text { Mean }\end{array}$} & \multicolumn{2}{c|}{} \\
\hline $\begin{array}{l}\text { Final score LE2 } \\
\text { Final score LE3 }\end{array}$ & -1.15000 & .74516 & .16662 & -6.902 \\
\hline
\end{tabular}

Table 2. Paired samples test based on final scores for essays in LE2 and LE3

As can be seen, the paired samples test indicates a significant difference between the scores the students achieved for their essays in LE2 and the scores they achieved for their essays in LE3 $(t=6.902)$. This result confirms that the 
students wrote better essays in the experiment than they did at the end of the previous semester, thus speaking in favour of the first research question indicating that it may be expected that PBL in a CALL setting contributes to student writing skills.

In order to obtain statistically significant results confirming the second research question regarding the extent to which PBL will facilitate students' abilities to explore, select and use digital resources provided to them in a CALL environment to draft a written legal claim, an additional analysis had to be performed. Thus the individual scores achieved by the students for each defined criterion were compared in order to determine whether any statistically significant differences among the scores with respect to both evaluation criteria could be identified (see Table3).

\begin{tabular}{|c|c|c|c|c|c|}
\hline & & Mean & $\begin{array}{c}\text { Std. } \\
\text { Deviation }\end{array}$ & $\mathrm{t}$ & $\mathrm{p}$ \\
\hline $\mathrm{LE} 2 / \mathrm{C} 1$ & LE3/C1 & .84211 & .89834 & 4.086 & .001 \\
\hline LE2/C2 & $\mathrm{LE} 3 / \mathrm{C} 2$ & .52632 & .69669 & 3.293 & .004 \\
\hline
\end{tabular}

Table 3. Paired samples test based on final scores for both evaluation criteria in LE2 and LE3

As shown above, the differences between the two essays are statistically significant with respect to both criteria $(\mathrm{p}=-0.001$ and $\mathrm{p}=-004)$. However, it can be noticed that the achievement related to the second criterion (research question and quality of resources) is weaker than the achievement related to the first criterion (ideas) $(t=3.293$ as opposed to $t=4.086)$. Unfortunately, this result does not contribute to the expectation related to the second research question. In other words, the research did not confirm that PBL facilitates students' abilities to explore, select and use digital resources provided to them in a CALL environment to draft a written legal claim.

The reasons for this result could not be investigated within this research due to the limitations presented above. ${ }^{6}$ Nevertheless, a subjective conclusion based on prior practical experience gathered from classroom activities may be drawn. It predominantly points to the students' general lack of skill for autonomous and independent writing which is especially noticed in the context of writing in LE. Since this particular skill requires that students master specific legal vocabulary, familiarize with the complexities of international law, understand the concepts related to it and express their thoughts and ideas in coherently organized essays, adding autonomous and independent research to all these did not contribute to a better writing performance.

\section{Conclusions and RECOMMENDATIONS FOR future study}

The initially proposed hypothesis of this research was only partially confirmed. In other words, if based on a CALL setting, PBL in an LE as an ESP

6 It is worth noting that due to the listed limitations, this experiment can be regarded only as quasi-experimental, thus serving as an illustration which is why future research would have to be conducted during a longer period and with a larger number of students. 
course proves effective only to a certain extent. The first research question was confirmed as the obtained results showed progress and better performance in the students' final written products submitted within the experiment in comparison to their previously measured writing performance. However, the second research question could not be confirmed as PBL does not seem to facilitate students' abilities to explore, select and use digital resources provided to them in a CALL environment when expected to draft a written legal claim. An obvious lack of skill for autonomous and independent writing based on research and resources remains a prominent weakness among students. The extent to which this conclusion holds true for other aspects of writing activities is still to be examined, alongside with the reasons causing these shortcomings.

Nevertheless, the results obtained in this research, as the research itself, indicate different directions of further investigations and research, some of which may be:

a) Evaluate and test various types of existing and verified ELT methodology based on CALL for different learning objectives, language skills and purposes;

b) Design and create new approaches and methods to be used in CALL based on traditional ones so that they may be used to further autonomous and independent learning especially at higher levels of educations;

c) Introduce appropriate changes to teaching systems to ensure the effective implementation of CALL, such as curriculum and syllabus adjustments, teacher training, assessment procedures, etc.

It may be expected that such research will not only provide a structured and systematic approach to CALL, but also a reliable framework for effective ELT methodology based on a broader implementation of CALL.

\section{References:}

Adams and Hamm 1996: D. Adams and M. Hamm, Cooperative learning: Critical thinking and collaboration across the curriculum, Springfield, IL: Charles C. Thomas, Publishers.

Authors of this article (2016)

Barrett et al. 2013: M. Barrett, M. Byram, I. Lázár, P. Mompoint-Gaillard and S. Philippou, Developing the intercultural competence through education, Strasbourg: Council of Europe Publishing.

Beatty 2013: K. Beatty, Teaching and researching: Computer-assisted language learning, London: Pearson Education.

Benson 2013: P. Benson, Teaching and researching: Autonomy in language learning, New York: Routledge.

Bereiter and Scardamalia 1999: C. Bereiter and M. Scardamalia, Schools as knowledge-building organizations. In D. Keating and C. Hertzmann (eds.), Today's children, tomorrow's society: The developmental Healthand Wealth of Nations, pp. 274-289, New York: Guilford. 
Brown 2000: H. D. Brown, Principles of language learning and teaching, New York: Longman.

Carless 2009: D. Carless, Revisiting the TBLT versus P-P-P Debate: Voices from Hong Kong, Asian Journal of English Language Teaching, 19, 49-66.

Cerezo 2015: L. Cerezo, Theoretical approaches to CALL research: Toward a psycholinguistic Perspective. In R. P. Leow, L. Cerezo and M. Baralt (eds.), A psycholinguistic approach to technology and language learning, pp. 23-46, Berlin: De Groyter Mouton.

Chapelle 1997: C. A. Chapelle, CALL in the year 2000: Still in search of research paradigms, Language Learning and Technology, 1(1), 19-43.

Cheng and Dörnyei 2007: H. F. Cheng and Z. Dörnyei, The use of motivational strategies in language instruction: the case of EFL teaching in Taiwan, Innovation in Language Learning and Teaching, 1(1), 153-174.

Colpaert 2006: J. Colpaert, Pedagogy-driven design for online language teaching and learning, CALICO Journal, 23(3), 477-497.

Cook 2013: V. Cook, Second language learning and language teaching, London: Hodder Education.

Diehl et al. 1999: W. Diehl, T. Grobe, H. Lopez and C. Cabral, Project-based learning: A strategy for teaching and learning, Boston: Center for youth development and education.

Dodge 1995: B. Dodge, Some thoughts about WebQuests. Available at http://webquest. org/sdsu/about_webquests.html

EUROCALL Research Policy Statement 2010. Available at http://www.eurocalllanguages.org/about/research-policy

Eyring 2001: J. L. Eyring, Experiential and negotiated language learning, Teaching English as a Second or Foreign Language, 3, 333-344.

Felix 2002: U. Felix, The web for constructivism approaches in language learning, ReCALL, 14(1), 2-15.

Fotos and Browne 2013: S. Fotos and C. M. Browne, New perspectives on CALL for second language classrooms, New York: Routledge.

Fried-Both 2002: D. L. Fried-Booth, Project work, Oxford University Press.

Gallagher et al. 1992: S. A. Gallagher, W. J. Stepien and H. Rosenthal, The effects of problem-based learning on problem solving, Gifted Child Quarterly, 36(4), $195-200$.

Giltrow et al. 2009: J. Giltrow, R. Gooding, D. Burgoyne and M. Sawatsky, Academic writing: An introduction, Ontario: Broadview Press.

Hall et al. 2011: G. Hall, G. Cook and R. Carter, Exploring English language teaching: Language in action, New York: Routledge.

Herring et al. 2014: M. C. Herring, M. J. Koehler and P. Mishra, Handbook of Technological Pedagogical Content Knowledge (TPCK) for Educators, New York: Routledge.

Hyland 2000: F. Hyland, ESL writers and feedback: Giving more autonomy to students, Language Teaching Research, 4(1), 33-54.

Kohonen et al. 2014: V. Kohonen, R. Jaatinen, P. Kaikkonen and J. Lehtovaara, Experiential learning in foreign language education, New York: Routledge. 
Krajcik et al. 1994: J. S. Krajcik, P. C. Blumenfeld, R. W. Marx and E. Soloway, A collaborative model for helping middle grade science teachers learn projectbased instruction, The Elementary School Journal, 94(5), 483-497.

Levy and Stockwell 2013: M. Levy and G. Stockwell, CALL dimensions: Options and issues in computer-assisted language learning, New York: Routledge.

Murphy 2008: L. Murphy, Supporting learner autonomy: Developing practice through the production of courses for distance learners of French, German and Spanish, Language Teaching Research, 12(1), 83-102.

Nim Park and Son 2009: C. Nim Park and J. B. Son, Implementing computerassisted language learning in the EFL classroom: Teachers' perceptions and perspectives, International Journal of Pedagogies and Learning, 5(2), 80-101.

Reeder et al. 2013: K. Reeder, T. Heift, J. Roche, S. Tabyanian, S. Schlickau and P. Gölz, Toward a theory of evaluation for second language learning media. In S. Fotos \& C. M. Browne (eds.), New perspectives on CALL for second language classrooms, pp. 255-279, New York: Routledge.

Scardamalia and Bereiter 1991: M. Scardamalia and C. Bereiter, Higher levels of agency for children in knowledge building: A challenge for the design of new knowledge media, The Journal of the Learning Sciences, 1(1), 37-68.

Simina and Hamel 2005: V. Simina and M. J. Hamel, CASLA through a social constructivist perspective: WebQuest in project-driven language learning, ReCALL, 17(2), 217-228.

Stephens and Randall 2011: D. L. Stephens and B. L. Randall, Culturally Proficient Collaboration: Use and Misuse of School Counselors, Thousand Oaks, CA: Corwin

Swan 2005: M. Swan, Legislation by hypothesis: The case of task-based instruction, Applied Linguistics, 26(3), 376-401.

Thomas et al. 1999: J. W. Thomas, J. R. Mergendoller and A. Michaelson, Projectbased learning: A handbook for middle and high school teachers, Novato, CA: The Buck Institute for Education.

Trentin 2009: G. Trentin, Using a wiki to evaluate individual contribution to a collaborative learning project, Journal of Computer Assisted Learning, 25(1), 43-55.

Tretten and Zachariou 1997: R. Tretten and P. Zachariou, Learning about projectbased learning: Assessment of project-based learning in Tinkertech schools, San Rafael, CA: The Autodesk Foundation.

Vanderplank 2010: R. Vanderplank, Déjà vu? A decade of research on language laboratories, television and video in language learning. Language Teaching, 43(1), 1-37. 


\section{Јасмина П. Ђорђевић \\ Савка Н. Благојевић \\ МЕТОД ИЗРАДЕ ПРОЈЕКТА УЗ ПРИМЕНУ РАЧУНАРА У НАСТАВИ ЈЕЗИКА: ПРИМЕР ИЗ ПРАВНОГ ЕНГЛЕСКОГ}

Резиме

Истраживање приказано овим радом има за циљ да испита ефикасност методе израде пројекта у посебно припремљеним условима, тј. уз примену рачунара, у циљу унапређења вештине писања у оквиру курса из правног енглеског језика. Почетна хипотеза у истраживању била је да метода израде пројекта примењена на овај начин може унапредити вештину писања код студената који изучавају правни енглески језик, те је у ту сврху инициран пројекат у трајању од две недеље у коме је 20 студената енглеског језика имало задатак да обради један проблем из правног енглеског језика, незаконити престанак радног односа, уз помоћ веб претраге као активности усмерене ка истраживању извора на интернету. Планирани исход пројекта био је да се утврди да ли студенти могу да напишу захтев на основу дигиталних ресурса понуђених у оквиру веб претраге. Вредновање написаних захтева које су студенти предали по завршеном задатку обављено је уз помоћ рубрика и оно указује да метода израде пројекта уз примену рачунара доприноси развоју вештине писања код студената у оквиру курса Правни енглески језик, али само до извесне мере. Анализа оцена које су студенти добили у експерименту указала је на њихов свеукупно бољи успех у поређењу са оним који су раније постизали у истој области. Међутим, претпоставка да ће овако примењена метода израде пројекта оспособити студенте да на одговарајући начин одаберу и примене ресурсе који су им понуђени, овим истраживањем није потврђена, чиме се отвара простор за испитивања разлога и узрока због којих се нису постигли жељени резултати.

Кључне речи: метода израде пројекта, примена рачунара у настави језика, правни енглески језик, вештина писања.

Примлен 24. марит 2017. голоине Прихваћен 7. аирита 2017. голине 